\title{
Functional antigen presenting cells generated from human dendritic cells (DC) derived induced pluripotent stem cell lines
}

\author{
Arvind Chhabra
}

From 30th Annual Meeting and Associated Programs of the Society for Immunotherapy of Cancer (SITC 2015) National Harbor, MD, USA. 4-8 November 2015

\section{Background}

Human induced pluripotent stem cells (iPS) represent a unique source to create donor specific cells of choice.

\section{Methods}

We here report the generation of induced pluripotent stem cell (iPS) lines from human dendritic cells (DC), through a non-integrating RNA virus, sendai virus, expressing the reprogramming factor genes.

\section{Results}

We show that among the $\mathrm{CD} 4, \mathrm{CD} 8$, and the monocyte populations derived from human peripheral blood derived leukocytes (PBL), monocyte derived DC consistently yield iPS lines than CD4 and CD8 T cells. We here show data from three iPS lines derived from the DC of two different individuals, an under 50 years old younger donor and an over 70 years old older donor. Detailed characterization of these iPS lines show that the lines exhibit normal karyotype and pluripotency phenotype, generated embryoid bodies (EB) that could yield hematopoietic stem cells (HSC) precursors that produced different blood lineage progenitors in a colony forming unit (CFU) assay, and effector $\mathrm{T}$ cells in an OP9-Delta-1 feeder based system. We also show that these DC-iPS lines can be re-differentiated into antigen presenting cells (APC), and these iPS-DC can efficiently present human melanoma associated antigenic epitope, MART-127-35, to antigen specific T cells.

\section{Conclusions}

Human DC derived iPS generated APC offer a unique resource to characterize their immunogenic potential in comparison with the peripheral blood derived APC, and also to study developmental process leading to generation of human APC.

Published: 4 November 2015

doi:10.1186/2051-1426-3-S2-P206

Cite this article as: Chhabra: Functional antigen presenting cells generated from human dendritic cells (DC) derived induced pluripotent stem cell lines. Journal for ImmunoTherapy of Cancer 2015 3(Suppl 2):P206.

University of Connecticut Health Center, Farmington, CT, USA

Submit your next manuscript to BioMed Central and take full advantage of:

- Convenient online submission

- Thorough peer review

- No space constraints or color figure charges

- Immediate publication on acceptance

- Inclusion in PubMed, CAS, Scopus and Google Scholar

- Research which is freely available for redistribution 